\title{
Don't forget the flies: dipteran diversity and its consequences for floral ecology and evolution
}

\author{
Robert A. Raguso ${ }^{1}$ (1)
}

Received: 2 December 2019 / Accepted: 6 January 2020 / Published online: 14 January 2020

(c) The Author(s) 2020

\begin{abstract}
The attention of the global pollination community has been drawn to food safety and other ecosystem services provided by pollinators, in light of decline in social bee populations. Despite intensified research on bees, recent studies have revealed important contributions of flies to pollination success, reproductive isolation and floral diversification. Diptera is a highly diverse insect order, comprising over 125,000 described species in 110 families and representing a broad spectrum of ecological niches beyond the well-known agricultural pests and blood-feeding vectors of human and animal diseases. Flies are most appreciated as generalized pollinators in alpine habitats (anthomyiids and tachinids) and as specialized pollinators in brood-site deceptive plants that mimic fungi (drosophilids), feces (muscids) or carrion (sarcophagids and calliphorids). Syrphid and bombyliid flies visit many of the same flowers as bees and butterflies do, but with different impacts on plant fitness. Guilds of South African plants have evolved specialized relationships with long-tongued nemestrinid and tabanid flies, thanks to geographic isolation and climatic stability. Studies in Japan highlight the evolution of another plant guild, pollinated by sciarid and mycetophilid fungus gnats, whereas Zygothrica flies (Drosophilidae) pollinate mushroom-like Dracula orchids in Andean cloud forests.
\end{abstract}

Keywords Deception $\cdot$ Diversification $\cdot$ Mutualism $\cdot$ Pollination $\cdot$ Parasitism

\section{Introduction}

Since the publication of "The Forgotten Pollinators" (Buchmann and Nabhan 1996), there has been a concerted effort to expand studies of plant-pollinator interactions across several scales (landscape, geographic, phylogenetic) and contexts (biodiversity, mutualism, ecosystem services and agriculture) (Garibaldi et al. 2013; Potts et al. 2016; Ricketts et al. 2008). One outcome of expanded global attention to plant-pollinator dynamics has been the realization that populations of social bees, especially managed colonies of the European honey bee (Apis mellifera) and wild species of bumble bee (Bombus spp.), are in global decline, with the predicted consequences of widespread economic and food security-related costs (Aizen and Harder 2009; Bartomeus et al. 2011; Potts et al. 2010). Despite their numerical dominance, social bees are not the only insect pollinators, nor are

Robert A. Raguso

rar229@cornell.edu

1 Department of Neurobiology and Behavior, Cornell University, Ithaca, NY 14853, USA they always the most efficient or important pollinators for all crop plants and their wild relatives (rev. by Rader et al. 2016, 2019). Another consequence of increased global awareness of pollinator vulnerability has been a growing appreciation for the diversity and abundance of flower-visiting flies (Diptera) and their potential as alternative pollinators (Mitra and Banerjee 2007; Orford et al. 2015; Ssymank et al. 2008). The order Diptera is highly diverse (125,000 spp., 110 families), with nearly every conceivable ecological niche represented in at least one fly lineage (Wiegmann et al. 2011). A series of recent reviews has documented the taxonomic diversity of flower-visiting Diptera (Larson et al. 2001), the fitnessrelated rewards and sensory traits that attract flies to flowers (Lunau 2014; Woodcock et al. 2014) and the available evidence describing how different fly groups seek food, brood sites and mates at flowers (Inouye et al. 2015). Considering the comprehensive nature of these recent reviews, my goal in this short review is to highlight a subset of dipteran families to make more generalized points about the ecology and evolution of fly pollination. Below, I outline some of the proximate mechanisms (e.g., sensory aspects) and ultimate causes (nutritional vs. reproductive imperatives) compelling 
flies to visit flowers, with a special focus on recent studies documenting the mediation of obligate mutualism and deception by floral volatiles.

\section{Food reward-based fly pollination: the nutritional spectrum}

Certain fly lineages have been well studied for their importance as pollinators of nectar- and/or pollen-rewarding flowers worldwide. Taken as a group, these flies visit flowers to satisfy adult nutritional needs, showing a range of generalized to specialized foraging behaviors. On one end of this spectrum are the hoverflies (Syrphidae), whose generalized foraging habits, capacity for flower constancy and global distribution suggest their potential as surrogate pollinators where bees are absent or in decline (Goulson and Wright 1998; Jauker and Wolters 2008; Rader et al. 2013). Because syrphids are diverse in form and ecology, it has proven difficult to generalize about their quality as pollinators. For example, different syrphid fly species vary in their pollen transfer effectiveness and interplant movement patterns when visiting flowers of common mustards (Brassica spp.; Gervasi and Schiestl 2017; Jauker and Wolters 2008; Rader et al. 2013; Saunders and Rader 2019). Behavioral experiments reveal that small, yellow-colored floral markings (akin to anthers with yellow pollen) release innate proboscis extension behavior in flower-naïve syrphids (Lunau and Wacht 1994). However, syrphids do not universally prefer yellow flowers and can demonstrate local preferences to different flower color-shape-scent combinations across continental distributions (Nordström et al. 2017). In some cases, syrphid flies with aphid-eating larvae are lured by orchid flowers that engage in chemical deception by emitting compounds that mimic aphid alarm pheromones, which are presumably used by female syrphids to find aphid populations (Stökl et al. 2011). This is an unusual case of syrphid fly pollination by brood-site deception (see below).

On the other end of the generalist-specialist spectrum are the tangle-veined flies (Nemestrinidae), which are most prevalent in South Africa, where plants from many families utilize them as their primary, specialized pollinators (Goldblatt and Manning 2000). Although nectar-feeding flies with mouthparts exceeding their body lengths have evolved independently in the Bombyliidae and Acroceridae (Grant and Grant 1965), these flies are more often members of mixed pollinator assemblages along with small bees and butterflies (Miller et al. 2013; Thompson and Pellmyr 1992). In contrast, long-tongued Nemestrinidae and Tabanidae represent a distinct pollinator niche in southern Africa, driving the evolution of specialized guilds of plants with colorful, scentless (or weakly scented), long-tubed flowers across South African habitats (e.g., fynbos, succulent karoo, grassland; Anderson and Johnson 2009; Goldblatt and Manning 2000). Visual signals, including flower color and conspicuous nectar-guide patterns, are important in flower choice and handling (via proboscis placement) by long-tongued flies, enhancing pollen movement (Hansen et al. 2011). Convergent evolution of floral color and shape appears to drive Batesian mimicry of nectar-rich plants by nectarless Disa orchids (Johnson and Morita 2006; Johnson and Steiner 1997), resulting in increased outcrossing rates for the orchids due to fly movement between nectarless plants (Jersáková and Johnson 2006).

Recent studies in Japan revealed the presence of another guild of convergently evolved, fly-pollinated plants, long overlooked within a well-studied flora, in this case utilizing nectar-foraging fungus gnats (Mycetophilidae and Sciaridae) as pollinators (Mochizuki and Kawakita 2017). Previous studies had detailed an obligate relationship between long-tongued gnats and tiny Mitella flowers (Saxifragaceae), distinguished by their red or green color, highly divided petals and distinctive scents (lilac aldehydes and alcohols; Okamoto et al. 2015). Mochizuki and Kawakita (2017) describe the repeated evolution of such flowers in the East Asian flora (families Garryaceae, Celastraceae, Hamamelidaceae, and Liliaceae), pollinated by mycetophilids and sciarids during spring and fall, at dusk.

Calyptrate flies (including Muscidae, Calliphoridae, Tachinidae and other families of bristle-covered flies) are best known as pollinators of brood-site deception, including those mimicking dung and carrion (rev. by Jürgens et al. 2013; Urru et al. 2011; see below). Nevertheless, these flies frequently visit non-mimetic flowers seeking more conventional nutritious rewards and are becoming more appreciated for their importance as pollinators (Orford et al. 2015). At a landscape scale, calyptrate flies are more prevalent flower visitors and pollinators in habitats where their life cycles are enhanced by human activities, such as dairy farms and livestock pens (Saunders and Rader 2019). Calyptrate flies often are observed to be numerically dominant flower visitors in high altitude and/or high latitude biomes worldwide (rev. by Kearns 1992; Larson et al. 2001), especially for plants in the Apiaceae with white or dull-colored umbels, unpleasant (to humans) scents and accessible nectar (e.g., Pastinaca sativa; Jogesh et al. 2014).

\section{Obligate mutualism and brood-site deception: the reproductive spectrum}

Pollination biologists less frequently consider the cases in which insects visit flowers to promote their reproductive success, rather than to acquire nutritional rewards (see 
Bernhardt 2000; Pellmyr and Thien 1986). Considered broadly, reproduction-related floral resources range from mate rendezvous sites (Johnson and Dafni 1998) to oviposition sites needed by larvae (Sakai 2002). Thus, the spectrum of pollination systems in the reproductive category extends not only from the specialized to the generalized (as with nectar- and pollen-driven systems described above) but more importantly, from obligate mutualism to deception.

Cases of obligate mutualism are well documented for fly-pollinated plants including the "nursery pollination" of globe flowers (Trollius europaeus; Ranunculaceae) by Chiastochaeta flies (Anthomyiidae; Ibanez et al. 2010) and of Alocasia odora (Araceae) by Colocasiomyia flies (Drosophilidae; Miyake and Yafuso 2003). Sakai (2002) distinguished between three larval resource classes in nursery pollination mutualisms: ovules, pollen and decaying (non-gametic) tissues from flowers or inflorescences. Sakai (2002) noted that these three classes of brood-site resources differ in degree of specialization (i.e., ovule-utilizing insects are more specialized than those utilizing anthers or pollen as a brood resource) and in the selective pressures experienced by the host plant. For example, ovule-based nursery pollination systems may evolve host sanctions (e.g., selective abortion of developing fruits) to select against the offspring of pollinators that "defect" on the mutualism by laying too many eggs into fig ovules (Jandér and Herre 2010) or may evolve counter-adaptations to reduce ovule loss when alternative (and more benign) pollinators are present (Thompson and Cunningham 2002).

In contrast, nursery mutualisms in which the pollinators' larvae utilize non-gametic floral tissues (or microbes growing upon them) obviate the need for sanctions, because larvae feed on tissues physically removed from fertilized ovules, in some cases after flowers abscise and fall to the forest floor (Sakai et al. 2000). Because many non-pollinating insects feed on rotting flowers or their microbial symbionts, such post-pollination nursery pollination systems tend not to be as specialized as ovule-based obligate mutualism. When pollinator relationships are specialized, as in the case of Alocasia aroids, specialization is mediated by the chemical composition of floral volatile attractants (a partner choice mechanism; see Hossaert-McKey et al. 2010), the enclosure of sexually mature florets within a chamber-forming spathe and the timing (phenology) of both chemical and physical "filters" that restrict broader visitor access to floral tissues (Miyake and Yafuso 2003).

Less common than nursery pollination, which is driven by mated female insects, are systems in which unmated male insects visit flowers to collect materials used in courtship. Although the acquisition of "aphrodisiac" volatile oils from flowers is well documented for male orchid bees (Euglossinae; Apidae) in the Neotropics (Zimmermann et al. 2009; Hetherington-Rauth and Ramírez
2016), a parallel system has evolved in the orchid genus Bulbophyllum in the Malay Archipelago, pollinated by male fruit flies (Tephritidae; Tan and Nishida 2000). The orchids emit volatile phenylpropanoids (methyl eugenol, raspberry ketone, zingerone) and related compounds, with complex phylogeographical patterns that reflect the sensory biases of different Bactrocera and Zeugodacus fly species (Nakahira et al. 2018). As in the case of euglossine bee-pollinated Neotropical orchids, tephritid fly-pollinated Bulbophyllum orchids have complex color patterns and morphological structures that compel male flies to lose their balance and thereby acquire and deposit pollinia (Tan and Nishida 2000). However, in both cases, primary attraction to the orchid flowers is olfactory.

Floral mimicry and deception are driven by cognitive misclassification, in which pollinators mistake deceptive flowers for other objects (rewarding flowers, brood sites, mates) important to their adult biology (Johnson and Schiestl 2016). Obligate mutualism in which pollinators visit flowers for reproductive purposes is especially vulnerable to floral deception because of strong selective pressure to respond (and not habituate) to the sensory cues of brood sites and mates. The chemical ecology of brood-site deception is best understood in fly-pollinated systems involving the mimicry of dung (oligosulfides) or carrion (cresol and indole; Jürgens et al. 2013; Urru et al. 2011), with recent studies elucidating brood-site mimicry of rotting fruit, sap or yeasts nurtured by these substrates (small aliphatic alcohols and esters; Martos et al. 2015; Stökl et al. 2010). Brood-site deceptive flowers or inflorescences often take the form of kettle traps, to which duped insects are attracted by volatile compounds, and within which they are held captive as a mechanism for ensuring pollen placement or transfer (Bernhardt 2000, Burgess et al. 2004; Chartier et al. 2014; Heiduk et al. 2015). Furthermore, many brood-site deceptive plants are thermogenic, presumably because heat is an important cue attracting flies to dead or decaying substrates (Angioy et al. 2004; Schiestl 2017). Interestingly, neither floral chambers (Meve and Liede 1994) nor heat (Burgess et al. 2004) are necessary to persuade female flies to oviposit into broodsite deceptive flowers.

An intriguing theme to emerge from research on broodsite deception is that pollinator specialization often results from the combined effects of chemical and morphological "floral filters" (Johnson et al. 2006; Raguso 2008). For example, Gastrodia similis orchids use a blend of volatile esters to attract a subset of the drosophilid fly community that breeds on fallen fruit in the rainforest understory of Reunion Island, but only one of these species (Scaptodrosophila bangi) can fit through the aperture of the floral chamber (Martos et al. 2015), similar to the way that fig wasps find and enter figs. Similarly, Orbea lutea (Apocynaceae) attracts a spectrum of carrion flies to their large, sulfide-scented flowers in the 
grasslands of southern Africa, but of these visitors, only Atherigona (Muscidae) flies are small enough to fit within the morphological gap formed by the inner corona lobes and, thus, effectively transfer pollinia (Shuttleworth et al. 2017).

Sexual deception was not thought to be common in flypollinated systems, but recent studies indicate high taxonomic diversity and a global reach for this mode of pollination. Rewardless Andean orchids in the genera Trichoceros and Telipogon have long been suspected of sexual deception, using male tachinid flies as dupes (van der Pijl and Dodson 1966). Recent work by Martel et al. (2016) demonstrated that the flowers of Telipogon peruvianus attract male Eudejeania tachinid flies as pollinators. Chemical and behavioral analyses revealed that these flowers mimic both the cuticular hydrocarbon blend used by female Eudejeania flies to attract males and the yellow ray florets of the aster flowers upon which male flies seek mates in montane habitats (Martel et al. 2019). A similar system occurs in northwestern South Africa, in which male Megapalpus capensis flies (Bombyliidae) are attracted to modified ray florets of the daisy Gorteria diffusa (Johnson and Midgley 1997). Subsequent experiments have shown that female $M$. capensis flies drink nectar from flowers of $G$. diffusa, that male flies visit these flowers seeking females, that males mistake dark callus on ray florets as females and attempt to copulate with them, and that male visits enhance Gorteria pollen flow beyond distances moved by females (Ellis and Johnson 2010). Pollination by pseudo-copulation also has been discovered in Lepanthes orchids growing in Costa Rican cloud forest habitats, in which male fungus gnats (Bradysia floribunda; Sciaridae) may ejaculate a spermatophore onto the flower (Blanco and Barboza 2005). Because there are more than 800 described species in the genus Lepanthes, all with rewardless flowers, sexual deception by flies may be far more widespread than has been appreciated.

\section{Blurring the boundaries-mixed modes and unusual niches}

One problem inherent to the study of pollination is the hazard of assigning plant-pollinator interactions to exclusive categories (Fenster et al. 2004). For the purpose of this review, I have distinguished between pollination systems driven by the acquisition of adult nutrition (nectar and pollen) and those driven by reproductive processes (mating, oviposition). However, in practice, the boundaries between these categories often become blurry. The G. diffusa daisies described above combine nectar rewards and sexual deception to affect pollination by female and male bombyliid flies, respectively (Ellis and Johnson 2010), a reminder that many insects use flowers as rendezvous sites for mating (Spaethe et al. 2007). Moreover, brood-site deceptive systems with kettle trap flowers often provide nectar or other nutritious secretions to their trapped pollinators (Chartier et al. 2014; Woodcock et al. 2014), reflecting the common observation that adult dung flies and carrion flies often feed from these substrates (Jürgens et al. 2013). Recent studies of Dracula lafleurii orchids in Ecuador indicate that both sexes of Zygothrica (Drosophilidae) flies treat the mushroom-mimicking flowers as if they were host mushrooms, at which they court, mate, wage territorial contests and feed on surface-growing yeasts (Endara et al. 2010). The lone difference is the observation that these flies do not oviposit on the orchid flowers, as their larvae do not reach maturity when cultured on $D$. lafleurii floral tissues (Policha et al. 2019). Behavioral studies revealed that mushroom-mimicking labellum volatiles attract the flies to the orchids, but additional chemical cues on the umbrella-like sepals are necessary to mediate the full spectrum of fly behaviors leading to pollination (Policha et al. 2016).

The greatest challenge to understanding the full spectrum of fly pollination is our collective ignorance of the life history details and ecological niches of many/most dipteran lineages (Larson et al. 2001). For example, we now know that pollination by tiny kleptoparasitic frit flies (Chloropidae) can be accomplished either by feeding them nectar from flowers too small or too unapparent to be visited by more conventional pollinators (Genoplesium littorale [Orchidaceae]; Bower et al. 2015), providing them with a protected, pollenbased brood site (Peltandra virginica [Araceae]; Patt et al. 1995) or luring them to kettle traps whose volatiles mimic the odors of wounded or (spider-) killed insects (Aristolochia rotunda [Aristolochiaceae]; Oelschlägel et al. 2015). The convergent evolution of a volatile-mediated kettle trap in chloropid-pollinated Ceropegia dolichophylla (Apocynaceae; Heiduk et al. 2015) suggests that an important pollination niche has been overlooked. Bogarín et al. (2018) describe a similar case of convergent evolution for pollination by biting midges (Ceratopogonidae), including species of Trichosalpinx and Bulbophyllum orchids, different species of Aristolochia and Ceropegia, as well as Theobroma cacao (Malvaceae), the natural source of chocolate. In this case, attraction of female flies appears to involve the provision of small amounts of floral protein, dark, hirsute floral structures and cuticular chemistry recalling animal skin or sebaceous gland secretions.

\section{Conclusions}

We are just beginning to appreciate the full spectrum of pollinator niches associated with dipteran diversity, as many of the studies described here represent much larger lineages of both plants and pollinators. The careful studies of Borba and Semir $(1998,2001)$ in the Campos Rupestres of eastern 
Brazil indicate highly specialized relationships between Bulbophyllum and Pleurothallis orchids and chloropid, milichiid and phorid fly pollinators, mediated by complex morphological, visual and chemical mechanisms. Yet, these two orchid genera account for over 3500 described species, most with unknown reproductive biology. Similarly, our rapidly growing knowledge of pollinator identity, behavior and diversity in the kettle trap genera Aristolochia (over $450 \mathrm{spp}$ ) and Ceropegia (c. 200 spp) highlights the involvement of an unanticipated diversity of fly lineages as pollinators (Berjano et al. 2009; Ollerton et al. 2017). Given that many of these lineages include economically important pests, parasites, disease vectors and/or may provide important resources to other such organisms, there are compelling reasons to justify increased research activity on pollination by flies.

Acknowledgments This mini-review presents vignettes from an invited plenary talk presented at the 25th International Symposium of the Japanese Society for Applied Entomology and Zoology (Tsukuba, Japan; March 25-27, 2019). I am most grateful to Prof. Shigeru Matsuyama for the invitation to this symposium and for his kind hospitality in Tsukuba. My sincere thanks also to Profs. Ritsuo Nishida, Shoko Sakai and Takashi Miyake, along with Drs. Yudai Okuyama, Tomoko Okamoto and Ko Mochizuki for stimulating discussions about the evolution of fly pollination and its chemical ecology, and for their inspiring research on this subject. Special thanks to Jeff Ollerton and two anonymous reviewers for constructive suggestions and editorial improvements.

Open Access This article is licensed under a Creative Commons Attribution 4.0 International License, which permits use, sharing, adaptation, distribution and reproduction in any medium or format, as long as you give appropriate credit to the original author(s) and the source, provide a link to the Creative Commons licence, and indicate if changes were made. The images or other third party material in this article are included in the article's Creative Commons licence, unless indicated otherwise in a credit line to the material. If material is not included in the article's Creative Commons licence and your intended use is not permitted by statutory regulation or exceeds the permitted use, you will need to obtain permission directly from the copyright holder. To view a copy of this licence, visit http://creativecommons.org/licenses/by/4.0/.

\section{References}

Aizen MA, Harder LD (2009) The global stock of domesticated honey bees is growing slower than agricultural demand for pollination. Curr Biol 19:915-918. https://doi.org/10.1111/gcb.14736

Anderson B, Johnson SD (2009) Geographical covariation and local convergence of flower depth in a guild of fly-pollinated plants. New Phytol 182:533-540. https://doi.org/10.111 $1 / \mathrm{j} .1469-8137.2009 .02764 . x$

Angioy AM, Stensmyr MC, Urru I, Puliafito M, Collu I, Hansson BS (2004) Function of the heater: the dead horse arum revisited. P Roy SocB-Biol Sci 271:S13-S15. https://doi.org/10.1098/ rsbl.2003.0111

Bartomeus I, Ascher JS, Wagner D, Danforth BN, Colla S, Kornbluth S, Winfree R (2011) Climate-associated phenological advances in bee pollinators and bee-pollinated plants. Proc Natl Acad Sci USA 108:20645-20649. https://doi.org/10.1073/pnas.1115559108
Berjano R, Ortiz PL, Arista M, Talavera S (2009) Pollinators, flowering phenology and floral longevity in two Mediterranean Aristolochia species, with a review of flower visitor records for the genus. Plant Biol 11:6-16. https://doi.org/10.1111/j.1438-8677.2008.00131.x

Bernhardt P (2000) Convergent evolution and adaptive radiation of beetle-pollinated angiosperms. In: Dafni A, Hesse M, Pacini E (eds) Pollen and pollination. Springer, Vienna, pp 293-320. https ://doi.org/10.1007/978-3-7091-6306-1_16

Blanco MA, Barboza G (2005) Pseudocopulatory pollination in Lepanthes (Orchidaceae: Pleurothallidinae) by fungus gnats. Ann Bot Lond 95:763-772. https://doi.org/10.1093/aob/mci090

Bogarín D, Fernández M, Borkent A, Heemskerk A, Pupulin F, Ramírez S, Smets E, Gravendeel B (2018) Pollination of Trichosalpinx (Orchidaceae: Pleurothallidinae) by biting midges (Diptera: Ceratopogonidae). Bot J Linn Soc 186:510-543. https://doi. org/10.1093/botlinnean/box087

Borba EL, Semir J (1998) Wind assisted fly pollination in three Bulbophyllum (Orchidaceae) species occurring in the Brazilian Campos Rupestres. Lindleyana 13:203-218

Borba EL, Semir J (2001) Pollinator specificity and convergence in fly-pollinated Pleurothallis (Orchidaceae) species: a multiple population approach. Ann Bot Lond 88:75-88. https://doi. org/10.1006/anbo.2001.1434

Bower CC, Towle B, Bickel D (2015) Reproductive success and pollination of the Tuncurry midge orchid (Genoplesium littorale) (Orchidaceae) by chloropid flies. Telopea 18:43-55

Buchmann SL, Nabhan GP (1996) The forgotten pollinators. Island Press, Washington

Burgess KS, Singfield J, Melendez V, Kevan PG (2004) Pollination biology of Aristolochia grandiflora (Aristolochiaceae) in Veracruz, Mexico. Ann MO Bot Gard 91:346-356. https://www. jstor.org/stable/3298612

Chartier M, Gibernau M, Renner SS (2014) The evolution of pollinator-plant interaction types in the Araceae. Evolution 68:15331543. https://doi.org/10.1111/evo.12318

Ellis AG, Johnson SD (2010) Floral mimicry enhances pollen export: the evolution of pollination by sexual deceit outside of the Orchidaceae. Am Nat 176: E143-E151. https://www.journals. uchicago.edu/doi/full/10.1086/656487

Endara L, Grimaldi D, Roy BA (2010) Lord of the flies: pollination of Dracula orchids. Lankesteriana 10:1-11

Fenster CB, Armbruster WS, Wilson P, Dudash MR, Thomson JD (2004) Pollination syndromes and floral specialization. Annu Rev Ecol Evol S 35:375-403. https://doi.org/10.1146/annur ev.ecolsys.34.011802.132347

Garibaldi LA, Steffan-Dewenter I, Winfree R, Aizen MA, Bommarco R, Cunningham SA, Kremen C, Carvalheiro LG, Harder LD, Afik O, Bartomeus I et al (2013) Wild pollinators enhance fruit set of crops regardless of honey bee abundance. Science 339:1608-1611. https://doi.org/10.1126/science.1230200

Gervasi DD, Schiestl FP (2017) Real-time divergent evolution in plants driven by pollinators. Nat Commun 8:14691. https:// www.nature.com/articles/ncomms14691

Goldblatt P, Manning JC (2000) The long-proboscid fly pollination system in Southern Africa. Ann Mo Bot Gard 87:146-170. https ://doi.org/10.2307/2666158

Goulson D, Wright NP (1998) Flower constancy in the hoverflies Episyrphus balteatus (Degeer) and Syrphus ribesii (L.)(Syrphidae). Behav Ecol 9:213-219. https://doi.org/10.1093/behec $\mathrm{o} / 9.3 .213$

Grant V, Grant KA (1965) Flower pollination in the Phlox family. Columbia University Press, New York, p 224

Hansen DM, Van der Niet T, Johnson SD (2011) Floral signposts: testing the significance of visual 'nectar guides' for pollinator behaviour and plant fitness. P Roy Soc B-Biol Sci 279:634-639. https://doi.org/10.1098/rspb.2011.1349 
Heiduk A, Kong H, Brake I, von Tschirnhaus M, Tolasch T, Tröger A, Wittenberg E, Francke W, Meve U, Dötterl S (2015) Deceptive Ceropegia dolichophylla fools its kleptoparasitic fly pollinators with exceptional floral scent. Front Ecol Evol 3:66. https ://doi.org/10.3389/fevo.2015.00066

Hetherington-Rauth MC, Ramírez SR (2016) Evolution and diversity of floral scent chemistry in the euglossine bee-pollinated orchid genus Gongora. Ann Bot London 118:135-148. https:// doi.org/10.1093/aob/mcw072

Hossaert-McKey M, Soler C, Schatz B, Proffit M (2010) Floral scents: their roles in nursery pollination mutualisms. Chemoecology 20:75-88. https://doi.org/10.1007/s00049-010-0043-5

Ibanez S, Dötterl S, Anstett MC, Baudino S, Caissard JC, Gallet C, Després L (2010) The role of volatile organic compounds, morphology and pigments of globeflowers in the attraction of their specific pollinating flies. New Phytol 188:451-463. https ://doi.org/10.1111/j.1469-8137.2010.03317.x

Inouye DW, Larson BM, Ssymank A, Kevan PG (2015) Flies and flowers III: ecology of foraging and pollination. J Pollinat Ecol 16:115-133. https://doi.org/10.26786/1920-7603\%28201 $5 \% 2915$

Jandér KC, Herre EA (2010) Host sanctions and pollinator cheating in the fig tree-fig wasp mutualism. P Roy Soc B-Biol Sci 277:1481-1488. https://doi.org/10.1098/rspb.2009.2157

Jauker F, Wolters V (2008) Hover flies are efficient pollinators of oilseed rape. Oecologia 156:819. https://doi.org/10.1007/s0044 2-008-1034-x

Jersáková J, Johnson SD (2006) Lack of floral nectar reduces selfpollination in a fly-pollinated orchid. Oecologia 147:60-68. https ://doi.org/10.1007/s00442-005-0254-6

Jogesh T, Zangerl A, Stanley M, Berenbaum M (2014) Implications of enemy escape on chemically mediated interactions with mutualists: wild parsnip pollination in two hemispheres. J Pollinat Ecol 11:57-67. https://doi.org/10.26786/1920-7603\%282013\%296

Johnson SD, Dafni A (1998) Response of bee-flies to the shape and pattern of model flowers: implications for floral evolution in a Mediterranean herb. Funct Ecol 12:289-297. https://doi.org/10.1 046/j.1365-2435.1998.00175.x

Johnson SD, Midgley JJ (1997) Fly pollination of Gorteria diffusa (Asteraceae), and a possible mimetic function for dark spots on the capitulum. Am J Bot 84:429-436. https://doi.org/10.2307/24460 18

Johnson SD, Morita S (2006) Lying to Pinocchio: floral deception in an orchid pollinated by long-proboscid flies. Bot J Linn Soc 152:271-278. https://doi.org/10.1111/j.1095-8339.2006.00571.x

Johnson SD, Schiestl FP (2016) Floral mimicry. Oxford University Press, Oxford, UK

Johnson SD, Steiner KE (1997) Long-tongued fly pollination and evolution of floral spur length in the Disa draconis complex (Orchidaceae). Evolution 51:45-53. https://doi. org/10.1111/j.1558-5646.1997.tb02387.x

Johnson SD, Hargreaves AL, Brown M (2006) Dark, bitter-tasting nectar functions as a filter of flower visitors in a bird-pollinated plant. Ecology 87:2709-2716. https://doi.org/10.1890/00129658(2006)87\%5b2709:DBNFAA\%5d2.0.CO;2

Jürgens A, Wee SL, Shuttleworth A, Johnson SD (2013) Chemical mimicry of insect oviposition sites: a global analysis of convergence in angiosperms. Ecol Lett 16:1157-1167. https://doi. org/10.1111/ele.12152

Kearns CA (1992) Anthophilous fly distribution across an elevation gradient. Am Midl Nat 127:172-182. https://doi. org/10.2307/2426332

Larson BMH, Kevan PG, Inouye DW (2001) Flies and flowers: taxonomic diversity of anthophiles and pollinators. Can Entomol 133:439-465. https://doi.org/10.4039/Ent133439-4
Lunau K (2014) Visual ecology of flies with particular reference to colour vision and colour preferences. J Comp Physiol A 200:497512. https://doi.org/10.1007/s00359-014-0895-1

Lunau K, Wacht S (1994) Optical releasers of the innate proboscis extension in the hoverfly Eristalis tenax L. (Syrphidae, Diptera). J Comp Physiol A 174:575-579. https://doi.org/10.1007/BF002 17378

Martel C, Cairampoma L, Stauffer FW, Ayasse M (2016) Telipogon peruvianus (Orchidaceae) flowers elicit pre-mating behaviour in Eudejeania (Tachinidae) males for pollination. PLoS One 11:e0165896. https://doi.org/10.1371/journal.pone.0165896

Martel C, Francke W, Ayasse M (2019) The chemical and visual basis in the pollination of the neotropical sexually deceptive orchid Telipogon peruvianus (Orchidaceae). New Phytol 223:1989-2001. https://doi.org/10.1111/nph.15902

Martos F, Cariou ML, Pailler T, Fournel J, Bytebier B, Johnson SD (2015) Chemical and morphological filters in a specialized floral mimicry system. New Phytol 207:225-234. https://doi. org/10.1111/nph.13350

Meve U, Liede S (1994) Floral biology and pollination in stapeliads-new results and a literature review. Pl Syst Evol 192:99116. https://doi.org/10.1007/BF00985911

Miller TJ, Raguso RA, Kay KM (2013) Novel adaptation to hawkmoth pollinators in Clarkia reduces efficiency, not attraction of diurnal visitors. Ann Bot Lond 113:317-329. https://doi. org/10.1093/aob/mct237

Mitra B, Banerjee D (2007) Fly pollinators: assessing their value in biodiversity conservation and food security in India. Rec Zool Surv India 107:33-48

Miyake T, Yafuso M (2003) Floral scents affect reproductive success in fly-pollinated Alocasia odora (Araceae). Am J Bot 90:370376. https://doi.org/10.3732/ajb.90.3.370

Mochizuki K, Kawakita A (2017) Pollination by fungus gnats and associated floral characteristics in five families of the Japanese flora. Ann Bot London 121:651-663. https://doi.org/10.1093/ aob/mcx 196

Nakahira M, Ono H, Wee SL, Tan KH, Nishida R (2018) Floral synomone diversification of Bulbophyllum sibling species (Orchidaceae) in attracting fruit fly pollinators. BiochemSyst Ecol 81:86-95. https://doi.org/10.1016/j.bse.2018.10.002

Nordström K, Dahlbom J, Pragadheesh VS, Ghosh S, Olsson A, Dyakova O, Suresh SK, Olsson SB (2017) In situ modeling of multimodal floral cues attracting wild pollinators across environments. Proc Nat Acad Sci USA 114:13218-13223. https:// doi.org/10.1073/pnas.1714414114

Oelschlägel B, Nuss M, von Tschirnhaus M, Pätzold C, Neinhuis C, Dötterl S, Wanke S (2015) The betrayed thief-the extraordinary strategy of Aristolochia rotunda to deceive its pollinators. New Phytol 206:342-351. https://doi.org/10.1111/nph.13210

Okamoto T, Okuyama Y, Goto R, Tokoro M, Kato M (2015) Parallel chemical switches underlying pollinator isolation in Asian Mitella. J Evolution Biol 28:590-600. https://doi.org/10.1111/ jeb. 12591

Ollerton J, Dötterl S, Ghorpadé K, Heiduk A, Liede-Schumann S, Masinde S, Meve U, Peter CI, Prieto-Benítez S, Punekar S, Thulin M (2017) Diversity of Diptera families that pollinate Ceropegia (Apocynaceae) trap flowers: an update in light of new data and phylogenetic analyses. Flora 234:233-244. https://doi. org/10.1016/j.flora.2017.07.013

Orford KA, Vaughan IP, Memmott J (2015) The forgotten flies: the importance of non-syrphid Diptera as pollinators. P R Soc B-Biol Sci 282:20142934. https://doi.org/10.1098/rspb.2014.2934

Patt JM, French JC, Schal C, Lech J, Hartman TG (1995) The pollination biology of Tuckahoe, Peltandra virginica (Araceae). Am J Bot 82:1230-1240. https://doi.org/10.1002/j.1537-2197.1995. tb12656.x 
Pellmyr O, Thien LB (1986) Insect reproduction and floral fragrances: keys to the evolution of the angiosperms? Taxon 35:76-85. https ://doi.org/10.2307/1221036

Policha T, Davis A, Barnadas M, Dentinger BT, Raguso RA, Roy BA (2016) Disentangling visual and olfactory signals in mushroom-mimicking Dracula orchids using realistic three-dimensional printed flowers. New Phytol 210:1058-1071. https://doi. org/10.1111/nph.13855

Policha T, Grimaldi DA, Manobanda R, Troya A, Ludden A, Dentinger BT, Roy BA (2019) Dracula orchids exploit guilds of fungus visiting flies: new perspectives on a mushroom mimic. Ecol Entomol 44:457-470. https://doi.org/10.1111/een.12720

Potts SG, Biesmeijer JC, Kremen C, Neumann P, Schweiger O, Kunin WE (2010) Global pollinator declines: trends, impacts and drivers. Trends Ecol Evol 25:345-353. https://doi.org/10.1016/j. tree.2010.01.007

Potts SG, Imperatriz-Fonseca V, Ngo HT, Aizen MA, Biesmeijer JC, Breeze TD, Dicks LV, Garibaldi LA, Hill R, Settele J, Vanbergen AJ (2016) Safeguarding pollinators and their values to human well-being. Nature 540:220-229. https://doi.org/10.1038/natur e20588

Rader R, Edwards W, Westcott DA, Cunningham SA, Howlett BG (2013) Diurnal effectiveness of pollination by bees and flies in agricultural Brassica rapa: Implications for ecosystem resilience. Basic Appl Ecol 14:20-27. https://doi.org/10.1016/j. baae.2012.10.011

Rader R, Bartomeus I, Garibaldi LA, Garratt MP, Howlett BG, Winfree R, Cunningham SA, Mayfield MM, Arthur AD, Andersson GK, Bommarco R et al (2016) Non-bee insects are important contributors to global crop pollination. Proc Nat Acad Sci USA 113:146-151. https://doi.org/10.1073/pnas.1517092112

Rader R, Cunningham SA, Howlett BG, Inouye DW (2019) Non-bee insects as visitors and pollinators of crops: biology, ecology and management. Annu Rev Entomol 65:20.1-20.17. https://doi. org/10.1146/annurev-ento-011019-025055

Raguso RA (2008) Wake up and smell the roses: the ecology and evolution of floral scent. Annu Rev Ecol Evol S 39:549-569. https:// doi.org/10.1146/annurev.ecolsys.38.091206.095601

Ricketts TH, Regetz J, Steffan-Dewenter I, Cunningham SA, Kremen C, Bogdanski A, Gemmill-Herren B, Greenleaf SS, Klein AM, Mayfield MM, Morandin LA (2008) Landscape effects on crop pollination services: are there general patterns? Ecol Lett 11:499515. https://doi.org/10.1111/j.1461-0248.2008.01157.x

Sakai S (2002) A review of brood-site pollination mutualism: plants providing breeding sites for their pollinators. J Plant Res 115:0161-0168. https://doi.org/10.1007/s102650200

Sakai S, Kato M, Nagamasu H (2000) Artocarpus (Moraceae)-gall midge pollination mutualism mediated by a male-flower parasitic fungus. Am J Bot 87:440-445. https://doi.org/10.2307/2656640

Saunders ME, Rader R (2019) Network modularity influences plant reproduction in a mosaic tropical agroecosystem. P Roy Soc B-Biol Sci 286:20190296. https://doi.org/10.1098/rspb.2019.0296

Schiestl FP (2017) Innate receiver bias: its role in the ecology and evolution of plant-animal interactions. Ann Rev Ecol Evol S 48:585-603. https://doi.org/10.1146/annurev-ecolsys-11031 6-023039
Shuttleworth A, Johnson SD, Jürgens A (2017) Entering through the narrow gate: a morphological filter explains specialized pollination of a carrion-scented stapeliad. Flora 232:92-103. https://doi. org/10.1016/j.flora.2016.09.003

Spaethe J, Moser WH, Paulus HF (2007) Increase of pollinator attraction by means of a visual signal in the sexually deceptive orchid, Ophrys heldreichii (Orchidaceae). P1 Syst Evol 264:31-40. https ://doi.org/10.1007/s00606-006-0503-0

Ssymank A, Kearns CA, Pape T, Thompson FC (2008) Pollinating flies (Diptera): a major contribution to plant diversity and agricultural production. Biodiversity 9:86-89. https://doi.org/10.1080/14888 386.2008.9712892

Stökl J, Strutz A, Dafni A, Svatos A, Doubsky J, Knaden M, Sachse S, Hansson BS, Stensmyr MC (2010) A deceptive pollination system targeting drosophilids through olfactory mimicry of yeast. Curr Biol 20:1846-1852. https://doi.org/10.1016/j.cub.2010.09.033

Stökl J, Brodmann J, Dafni A, Ayasse M, Hansson BS (2011) Smells like aphids: orchid flowers mimic aphid alarm pheromones to attract hoverflies for pollination. P R Soc B-Biol Sci 278:12161222. https://doi.org/10.1098/rspb.2010.1770

Tan KH, Nishida R (2000) Mutual reproductive benefits between a wild orchid, Bulbophyllum patens, and Bactrocera fruit flies via a floral synomone. J Chem Ecol 26:533-546. https://doi. org/10.1023/A:1005477926244

Thompson JN, Cunningham BM (2002) Geographic structure and dynamics of coevolutionary selection. Nature 417:735-738. https ://doi.org/10.1038/nature00810

Thompson JN, Pellmyr O (1992) Mutualism with pollinating seed parasites amid co-pollinators: constraints on specialization. Ecology 73:1780-1791. https://doi.org/10.2307/1940029

Urru I, Stensmyr MC, Hansson BS (2011) Pollination by broodsite deception. Phytochemistry 72:1655-1666. https://doi. org/10.1016/j.phytochem.2011.02.014

van der Pijl L, Dodson CH (1966) Orchid flowers: their pollination and evolution. Fairchild Tropical Garden and Miami University Press, Coral Gables

Wiegmann BM, Trautwein MD, Winkler IS, Barr NB, Kim JW, Lambkin C, Bertone MA, Cassel BK, Bayless KM, Heimberg AM, Wheeler BM et al (2011) Episodic radiations in the fly tree of life. Proc Nat Acad Sci USA 108:5690-5695. https://doi.org/10.1073/ pnas. 1012675108

Woodcock TS, Larson BM, Kevan PG, Inouye DW, Lunau K (2014) Flies and flowers II: floral attractants and rewards. J Pollinat Ecol 12:63-94. https://doi.org/10.26786/1920-7603\%282014\%295

Zimmermann Y, Ramírez SR, Eltz T (2009) Chemical niche differentiation among sympatric species of orchid bees. Ecology 90:29943008. https://doi.org/10.1890/08-1858.1

Publisher's Note Springer Nature remains neutral with regard to jurisdictional claims in published maps and institutional affiliations. 